\title{
The potential of wild plants for phytoremediation of soil contaminated with mercury of gold cyanidation tailings
}

\author{
Nurul Muddarisna ${ }^{1}$, Baiq Dewi Krisnayanti ${ }^{2,3}$, Sri Rahayu Utami ${ }^{3}$, and \\ Eko Handayanto ${ }^{3}$ \\ 1) Postgraduate Program, University of Brawijaya, Jl. Veteran, Malang 65145, Indonesia \\ 2) Department of Soil Science, University of Mataram, Jl. Pendidikan 37, Mataram 83125, Indonesia \\ ${ }^{3)}$ International Research Centre for the Management of Degraded and Mining Lands (IRC-Medmind), \\ Soil Science Building, University of Brawijaya, Jl. Veteran, Malang 65145, Indonesia
}

\begin{abstract}
In artisanal and small-scale gold mine (ASGM) area of West Lombok, Indonesia, gold is recovered through a two-stage process of amalgamation and cyanidation. Tailing is discharged to land with no concern for contaminants in the tailings. Phytoremediation could cost-effectively replace traditional mercury remediation strategies. The objective of this study was to investigate the potential of six wild plant species (Lindernia crustacea (L.) F., Digitaria radicosa Miq., Zingiber purpurium Roxb., Paspalum conjugatum L., Cyperus kyllingia Endl., and Caladium bicolor L.) for phytoremediation of soil contaminated with mercury of gold cyanidation tailings. This study was conducted in a shade house located nearby a cyanidation processing facility of ASGM at Sekotong Distrik of West Lombok. Samples of tailings-uncontaminated soil were mixed with samples of cyanidation tailings with the proportion of 30\%: $70 \%(w / w)$. Each of the six plant seedlings was planted in a plastic pot containing $15 \mathrm{~kg}$ of soil-tailings mixture. At harvest (9 weeks), shoots and roots were analyzed for mercury concentration In general, the results indicated that none of the plant species were identified as hyperaccumulator. Based on BCFs, TFs, and BAC, L.crustacea, D.radicosa, P. conjugatum and C. kyllingia can be used for phytoextraction of $\mathrm{Hg}$ since they were efficient to take up and translocate mercury from roots to shoots. On the other hand, Z. purpureum and C. bicolor can be used for phytostabilization of mercury.
\end{abstract}

Keywords - gold mine, mercury, phytoextraction, tailings

\section{INTRODUCTION}

Indonesia is regarded as a major location for artisanal and small-scale gold mining (ASGM) activities. However, few monitoring or new-technology demonstration projects appear to have been conducted in Indonesia. It has been reported that there are 713 illegal small-scale mining sites throughout Sumatra, Java, Kalimantan and Sulawesi, with the majority of them ASGM [1]. One of ASGM areas in Indonesia is in West Lombok where gold is recovered by miners through a two-stage process of amalgamation and cyanidation. Tailings is discharged to land with no concern for contaminants in the tailings

Gold recovery at ASGM operations using cyanidation can be efficient (up to 95\% recovery) [2]. However, gold is not the only metal dissolved from the amalgamation tailings during cyanide leaching. Mercury will also form soluble complexes with cyanide, with the species dependant on $\mathrm{pH}$ although the rate of dissolution of mercury in cyanide is slower than that for gold [3]. Velasquez-Lopez et al. [4] reported a mercury balance for a carbon-in-pulp cyanidation circuit of amalgamation ore in Ecuador, and showed that approximately $27 \%$ of mercury in the feed material was leached over three days. A portion of this complexed mercury will be discharged with the tailings. Krisnayanti et al. [5] reported that the mean mercury concentration of the amalgamation tailings in ASGM area of West Lombok is about $3000 \mathrm{mg} \mathrm{kg}^{-1}$ and greater than $1600 \mathrm{mg}$ $\mathrm{kg}^{-1}$ for the cyanidation tailings. Therefore, the implications of this practice must be managed. What is necessary in handling ASGM in Indonesia is an environmental technology that can work alongside current operations to manage mercury pollution and generate synergistic benefits for affected communities.

Mercury-contaminated soils and sediments are commonly remediated by soil excavation, relocation, and burial; soil washing with halogenated substances; heating soil to high temperature; etc. However, a majority of these technologies are costly to implement and cause further disturbance to the already damaged environment. Phytoremediation that is a technology using various plants to degrade, extract, contain, or immobilize contaminants from soil and water could cost-effectively replace traditional mercury remediation strategies [6]. Among the different areas embraced by the field of phytoremediation, special interest has been devoted to the phytoextraction of metals from contaminated soils. In this case, metals are removed from soils by concentrating them in the aerial parts of the plant. Harvesting and disposal of shoot biomass allows the metal to be removed in significant quantities from the soil [7] [8]. There is some evidence that certain plant species have the ability to extract and accumulate mercury both from the atmospheric and soil sources [9]. Huckabee et al. [10] monitored 
levels of mercury in vegetation near the mercury mine at Almaden, Spain. Currently, however, no plant species with mercury hyperaccumulating properties has been identified. Patra and Sharma [11] reviewed mercury toxicity in plants. All physiological and biochemical processes in plants may be negatively affected by mercury when plants are exposed to mercury-contaminated soil, water or air. Gaseous emission of mercury from plants and foliar have long been observed and studied [12]. Suszcynsky and Shann [13] studied the accumulation, toxicity response, and $\mathrm{Hg}$ distribution in tobacco plants exposed to elemental mercury vapor in a specially designed chamber system and in plants root-exposed to ionic mercury. Plants exposed to elemental mercury vapor accumulated mercury in the shoots with no movement to roots (by day ten). Root-exposed plants showed accumulation of mercury in the roots with movement to shoots by day ten [13]. A study conducted by Hidayati et al. [14] indicated that various indigenous plant species, such as Paspalum sp., Cyperus sp., Caladium sp., Digitaria sp., Lindernia sp., and Zingiber sp., accumulated mercury of more than $20 \mathrm{mg} \mathrm{kg}-1$ in the aquatic environment of ASGM areas of West Java. It is argued that those native species are potential for remediation of mercury-contaminated soils.

The objective of this study was to search for suitable plant species for phytoextraction of mercurycontaminated soil. In this study, we focused on phytoextraction of mercury from contaminated soil by natural plant species Since there is no known mercury hyperaccumulator, six natural plant species (Lindernia crustacea (L.) F., Digitaria radicosa Miq., Zingiber purpurium Roxb., Paspalum conjugatum L., Cyperus kyllingia Endl., and Caladium bicolor $\mathrm{L}$.) were investigated for mercury accumulation in plant parts. Plant species that have the great effectiveness for phytoremediation of mercury through phytoextraction were identified..

\section{Materials AND MeTHODS}

This study was conducted in a shade house located nearby a cyanidation processing facility of ASGM at Sekotong Distrik of West Lombok $\left(115^{0} .46^{\prime}-116^{0} .20^{\prime} \mathrm{E}\right.$, and $\left.8^{0} .25^{\prime}-8^{0} .55^{\prime} \mathrm{S}\right)$, from July to December 2012. Samples of tailing-uncontaminated soil in the area were collected at $0-30 \mathrm{~cm}$ depth. The soil samples were air dried at room temperature for two weeks, and ground to pass through 2-mm sieve. Samples of cyanidation tailings collected from cyanidation facilities were also air dried for two weeks and ground to pass through a 2 $\mathrm{mm}$ sieve. The air dried tailings was mixed with the air dried soil sample with the proportion of 30\%: 70\% $(\mathrm{w} / \mathrm{w})$. The concentration of $\mathrm{Hg}$ in the soil-tailing mixture was determined using a F732-S Cold Atomic Absorption Mercury Vapor Analyzer (Shanghai Huaguang Instrument Company). Result of analysis showed that $\mathrm{Hg}$ concentration in soil-tailing mixture was $327 \mathrm{mg} \mathrm{kg}^{-1}$. This value was much higher than the tolerable mercury concentration of $0.002 \mathrm{mg} \mathrm{kg}^{-1}$ regulated by the Indonesian Ministry of Environment.

Lindernia crustacea L., Digitaria radicosa Miq., Zingiber purpurium Roxb., Paspalum conjugatum L., Cyperus kyllingia Endl., and Caladium bicolor L., used for this study were two-week old acclimatized seedlings previously collected from areas nearby cyanidation facility. Each of six seedlings was planted in a plastic pot containing $15 \mathrm{~kg}$ of soil-tailings mixture for 9 weeks. Six treatments were arranged in a randomized block design with three replicates. To ensure plant growth, all pots received basal fertilizers of N, P and $\mathrm{K}$ with rates equivalent to 100,50 and $20 \mathrm{~kg} \mathrm{ha}^{-1}$, respectively. During the experiment, water was regularly supplied to ensure that water was not limiting plant growth. At harvest ( 9 weeks), shoots and roots were separated, washed, weighed and oven dried at $40^{\circ} \mathrm{C}$ for 48 hours for $\mathrm{Hg}$ analysis using the method describe above. Data obtained were subjected to analysis variance followed by $5 \%$ last significance different test. Biological Concentration Factor (BCF) was calculated as mercury concentration ratio of plant roots to soil [15]. Translocation Factor (TF) was described as ratio of mercury in plant shoot to that in plant root [16] [17]. Biological Accumulation Coefficient (BAC) was calculated as ratio of mercury in shoots to that in soil [16] [17].

\subsection{Plant biomass}

\section{RESULTS AND DISCUSSION}

Plant growth was reflected by the increase of dry weight of roots and shoots. The presence of heavy metals including mercury $(\mathrm{Hg})$ in the soil at high concentrations exceeding the threshold can inhibit plant growth, except for plants that are genetically have the ability to tolerate and adapt to stress the element of metal in soil. Certain plants belonging to the accumulator developed several effective mechanisms to tolerate high levels of metals in the soil. All plants species studied have high tolerance to soil-contaminated with gold mine tailings containing mercury. This was demonstrated by the absence of inhibition of plant growth and no visible physical damage that showed symptoms of toxicity at all plants. A previous survey conducted on the aquatic areas around gold mining sites in West Java showed that these plants showing capability to accumulate mercury of more than $20 \mathrm{ppm}$ in the root and shoot [14]. At harvest of 9 weeks the root and shoot dry weights produced by P.conjugatum was not significantly different from that of C.kyllingia, L.crustacea, D.radicosa, Z. purpureum and C.bicolor. 


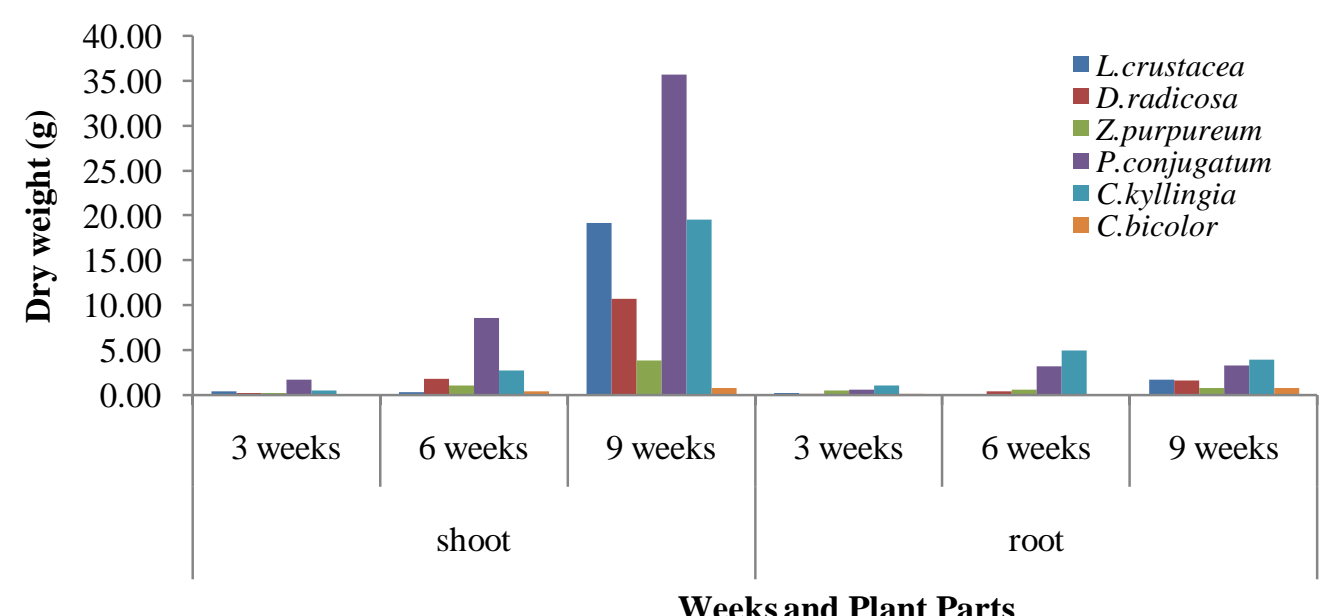

Figure1. Shoot and root dry weights of six wild plants grown on cyanidation tailings-soil mixtures for 9 weeks

\subsection{Mercury accumulation in plants}

Fig. 2 shows the concentrations of the mercury in the roots and shoots of L. crustacea, D.radicosa, Z.purpureum, P.conjugatum, C.kyllingia, and C.bicolor which were grown for 9 weeks. Significant differences $(\mathrm{p}<0.05)$ in mercury concentrations were observed for all plants studied. Analysis of variance revealed a significant effect of plant type on biological concentration factor (BCF) and bioaccumulation coefficient (BAC) of the plant. Except for C.bicolor and Z.purpureum, the shoots of plants showed higher values of mercury concentration than that observed in the roots. Therefore, the translocation factor (TF) (shoot/root calculated in terms of concentration), which is typically $>1$ in the case of accumulator species, was $>1$ for mercury of $L$. crustacea, D.radicosa, P.conjugatum, and C.kyllingia.

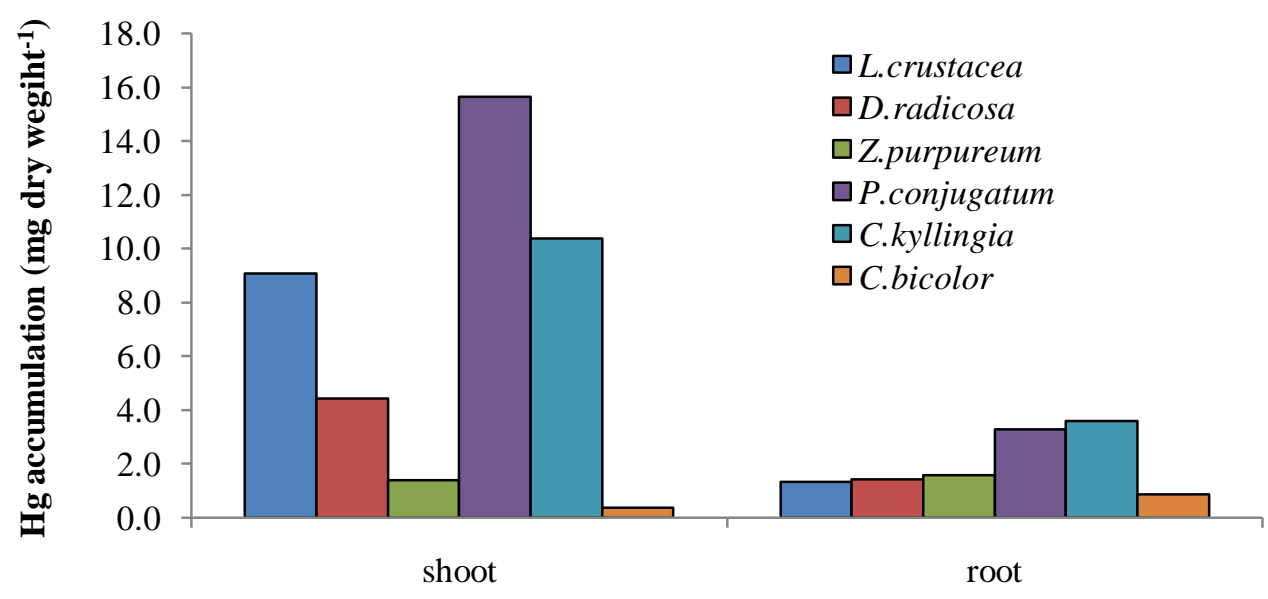

Plant Parts

Figure 2. Hg accumulation of shoots and roots of L. crustacea, D.radicosa, Z.purpureum, P.conjugatum, C.kyllingia, and C.bicolor grown on cyanidation tailings-soil mixtures for 9 weeks.

Mercury accumulation in the shoots of L. crustacea, P.conjugatum, and C.kyllingia were 9,06, 10.36 and $15,65 \mathrm{mg}$ dry weight ${ }^{-1}$, respectively. On the other hand, the corresponding values of D.radicosa, Z.purpureum, and C.bicolor were significantly $\left(\mathrm{p}<0.05\right.$ ) lower and reached only to $4.42,1.39$ and $0.36 \mathrm{mg}^{2}$ dry weight ${ }^{-1}$ weight, respectively. Concerning the values of mercury concentration measured in the shoots and roots of the studied plants, P.conjugatum accumulated more mercury than all other studied plants $(\mathrm{p}<0.05)$, and the levels of concentration was significant from the perspective of phytoextraction. Among the studied plant species screened for mercury, for plant species (L. crustacea, D.radicosa, P.conjugatum, and C.kyllingia) were efficient to take up and translocate mercury from roots to shoots as indicated by translocation factor (TF) (Table 1). The four 
plant species showed values of TF $>1$. The highest TF value was observed for L. crustacea (6.82), and the lowest was for C.bicolor (0.41).

Table 1 indicates that all plant species screened for mercury concentration showed value of BAC $<1$ that varied from 0.004 to 0.176 . Highest BAC values were found for P. conjugatum (0.176) and C. kyllingia (0.117) Similar patterns were observed for BCF in all studied plants.

Table 1. Biological Accumulation Coefficient (BAC), Biological Concentration Factor (BCF), and Translocation Factor (TF) of plant species for mercury.

\begin{tabular}{lccc}
\hline Plant species & $\begin{array}{c}\text { Biological Accumulation } \\
\text { Coefficient (BAC }\end{array}$ & $\begin{array}{c}\text { Biological Concentration } \\
\text { Factor (BCF) }\end{array}$ & $\begin{array}{c}\text { Translocation Factor } \\
(\mathrm{TF})\end{array}$ \\
\hline Lindernia crustacea & 0.102 & 0.015 & 6.82 \\
Digitaria radicosa & 0.050 & 0.016 & 3.11 \\
Zingiber purpureum & 0.016 & 0.018 & 0.88 \\
Paspalum conjugatum & 0.176 & 0.037 & 4.75 \\
Cyperus kyllingia & 0.117 & 0.040 & 2.88 \\
Caladium bicolor & 0.004 & 0.010 & 0.41 \\
\hline
\end{tabular}

\subsection{Discussion}

Large number of factors control metal accumulation and bioavailability associated with soil and climatic conditions, plant genotype and agronomic management, including: active/passive transfer processes, sequestration and speciation, redox states, the type of plant root system and the response of plants to elements in relation to seasonal cycles [18].

Heavy metals contamination of arable soil showed several problems, including phytotoxic effects of certain elements such as $\mathrm{Hg}$, which is well known to cause several phytotoxicities if critical level is exceeded [19] [20]. The total mean concentrations are all higher when compared with the value reported in other countries [21].

According to the results of this study, the plants studied can be regarded as heavy metal accumulators while they are different regarding their accumulating ability. The study also concludes that P.conjugatum can be considered as $\mathrm{Hg}$ accumulator plant especially its content in their shoot reached the highest concentration between the six plants studied. In addition, L. kyllingia, D. radicosa and L. curstacea can be regarded as $\mathrm{Hg}$ accumulator plants. High root to shoot translocation of $\mathrm{Hg}$ indicated that these four plant species have vital characteristics to be used in phytoextraction of metal [22] [23]. Plant species with slow plant growth, shallow root system and small biomass production are not generally preferred for phytoremediation. These four plant species had high biomass and based on high TF values could have enormous potential to be used for phytoextraction of $\mathrm{Hg}$ than other two plant species which showed $\mathrm{TF}<1$ for $\mathrm{Hg}$. Plant species with high $\mathrm{TF}$ values were considered suitable for phytoextraction generally requires translocation of heavy metals in easily harvestable plant parts i.e., shoots [15].

According to Ghosh and Singh [22] phytoextraction is a process to remove the contamination from soil without destroying soil structure and fertility. Great metal accumulation may be attributed to detoxification mechanism based on sequestration of heavy metal ions in vacuoles, by binding them on appropriate ligands such as organic acids, proteins and peptides in the presence of enzymes that can function at high level of metallic ions [16] and metal exclusion strategies of plant species [22].

In general, the results indicated that none of the plant species was identified as hyperaccumulator. To be recognized as a hyperaccumulator of one of the following metals, the minimum tissue concentrations are $0.01 \%$ by dry weight for $\mathrm{Cd}, 0.1 \%$ of $\mathrm{Ni}, \mathrm{Co}, \mathrm{Cu}, \mathrm{Cr}$ and/or Pg, and 1-3\% of $\mathrm{Zn}$ and/or Mn [24] [25] [26] [27] [28]. Since $\mathrm{Hg}$ is the third member of the Group IIb triad of the periodic table of elements along with zinc and cadmium, the minimum concentration of $\mathrm{Hg}$ in plant parts should be $0.01 \%$ dry weight or $100 \mathrm{mg} \mathrm{kg}^{-1}$. However, based on BCFs, TFs, and BAC values plant species were identified which have the potential for phytostabilization and phytoextraction. Based on TF values, Lindernia crustacea, Digitaria radicosa, Paspalum conjugatum and Cyperus kyllingia can be used for phytoextraction of $\mathrm{Hg}$ since they were efficient to take up and translocate $\mathrm{Hg}$ from roots to shoots. On the other hand, Zingiber purpureum and Caladium bicolor can be used for phytostabilization of $\mathrm{Hg}$.

\section{CONClusion}

L. crustacea, D.radicosa, $P$. conjugatum and C. kyllingia are four species of wild plants that have the potential to be used for phytoextraction of $\mathrm{Hg}$ contaminated soil. The capability of these four wild plant species to accumulate $\mathrm{Hg}$ was in the order of $L$. crustacea $>$ P.conjugatum $>$ D. radicosa $>C$. kyllingia. 


\section{- Acknowledgements}

This study was supported by Indofood Research Nugraha and the University of Brawijaya . Glasshouse and laboratory facilities provided by the Faculty of Agriculture, University of Brawijaya, and Faculty of Science, University of Mataram are gratefully acknowledged. Many thanks are due to Head of Sekotong District of West Lombok for providing unlimited access to the ASGM area of the district.

\section{REFERENCES}

[1] C. Aspinall, Small-scale mining in Indonesia. International Institute for Environment and Development and the World Business Council for Sustainable Development, England, 2001.

[2] L.D.Hylander, D. Plath, C.R. Miranda, S. Lucke, J. Ohlander, and A.T.F. Rivera, Comparison of different gold recovery methods with regard to pollution control and efficiency. Clean 35, 2007, 52-61.

[3] P. Cordy, M. Veiga, I. Salih, S. Al-Saadi, S. Console, O. Garcia, L. Mesa, P. Velasquez-Lopez and M. Roeser, Mercury contamination from artisanal gold mining in Antioquia, Colombia: The world's highest per capita mercury pollution. Science of the Total Environment 410-411, 2011, 154-160.

[4] P.C. Velasquez-Lopez, M.M. Veiga, B. Klein, J.A. Shandro and K. Hall, Cyanidation of mercury rich tailings in artisanal and smallscale gold mining: identifying strategies to manage environmental risks in Southern Ecuador. Journal of Cleaner Production 19, 2011, 1125-1133.

[5] B.D. Krisnayanti, C.W.N. Anderson, W.H. Utomo, X. Feng, E. Handayanto, N. Mudarisna, H. Ikram and Khususiah, Assessment of environmental mercury discharge at a four-year-old artisanal gold mining area on Lombok Island, Indonesia. Journal of Environmental Monitoring 14, 2012. 2598-2607.

[6] US Environmental Protection Agency, Introduction to Phytoremediation, EPA/600/R-99/107 (2000)

[7] A.Zayed, E.H.A. Pilot-Smits, M. de Souza, Z.Q. Lin, and N. Terry, Remediation of selenium-polluted soils and waters by phytovolatilisation, in N. Terry and G. Banuelos (eds), Phytoremediation of Trace Elements (Ann Arbor Press, Michigan, 2000), 6184.

[8] R.B. Meagher, C.L. Rugh, M.K. Kandasamy, G. Gragson, and N.J Wang, Engineering phytoremediation of mercury pollution in soil and water using bacterial genes. in N. Terry and G. Banuelos (eds), Phytoremediation of Contaminated Soil and Water (Lewis Publishers, USA, 2000), 201-219.

[9] I. Raskin, and B.D. Ensley, Phytoremediation of Toxic Metals: Using Plants to Clean Upthe Environment, (John Wiley \& Sons, New York, 2000).

[10] J.W. Huckabee, F.S. Diaz, S.A. Janzen, and J. Solomon, Distribution of Mercury in Vegetation at Almanden, Spain, Environmental Pollution Serie A 30, 1983, 211-224

[11] M. Patra, and A. Sharma, Mercury Toxicity in Plants, Botanical Reviews 66, 2000, 379-422.

[12] A.W. Rea, S.E. Lindberg, T. Scherbatskoy, and G.J. Keeler, Mercury Accumulation in Foliage over Time in Two Northern MixedHardwood Forests, Water Air \& Soil Pollution 133, 2002, 49-67.

[13] E.E. Suszcynsky, and J.R. Shann, Phytotoxicity and Accumulation of Mercury in Tobacco Subjected to Different Exposure Routes, Environmental Toxicology \& Chemistry 14,1995, 61-67.

[14] N. Hidayati, T. Juhaeti, dan F. Syarif, Mercury and Cyanide Contaminations in Gold Mine Environment and Possible Solution of Cleaning Up by Using Phytoextraction. Hayati Journal of Biosciences 16 (3), 2009, 88-94.

[15] J. Yoon, X. Cao, Q. Zhou and L.Q. Ma, Accumulation of Pb, $\mathrm{Cu}$, and $\mathrm{Zn}$ in native plants growing on a contaminated Florida site. Science of the Total Environment 368, 2006, 456-464.

[16] S. Cui, Q. Zhou and L. Chao, Potential hyperaccumulation of $\mathrm{Pb}, \mathrm{Zn}, \mathrm{Cu}$ and $\mathrm{Cd}$ in endurant plants distributed in an old smeltery, northeast China, Environmental Geology 51, 2007, 1043-1048.

[17] M.S. Li, Y.P. Luo and Z.Y. Su, Heavy metal concentrations in soils and plant accumulation in a restored manganese mineland in Guangxi, South China, Environmental Pollution 147, 2007, 168-175.

[18] A. Kabata-Pendias, and H. Pendias, Trace Elements in Soils and Plants (CRC Press, Florida,USA, 2000).

[19] K. Mengel, and E. Kirkby, Principles of Plant Nutrition (Kluwer Academic Publishers, Dordrecht, the Netherlands, 2001).

[20] A. Chehregani, B. Malayeri and R. Golmohammadi, Effect of heavy metals on the developmental stages of ovules and embryonic sac in Euphorbia cheirandenia, Pakistan Journal of Biological Science 8, 2005, 622-625.

[21] M.L. Pignata, G.L. Gudino, E.D. Wannaz, R.R. Pla, C.M. Gonzalez, H.A. Carreras and L. Orellana, Atmospheric quality and distribution of heavy metals in Argentina employing Tillandsia capillaries as a biomonitor, Environmental Pollution 120, 2002, 5968.

[22] M. Ghosh, and S.P. Singh, A review on phytoremediation of heavy metals and utilization of its byproducts, Applied Ecology and Environmental Research 3(1), 2005, 1-18.

[23] D.J. La'zaro, P.S. Kiddb and C.M. Martýnneza, A phytogeochemical study of the Tra's-os-Montes region (NE Portugal): Possible species for plant-based soil remediation technologies, Science of the Total Environment 354, 2006, $265-277$.

[24] S.D. Cunningham, and D.W. Ow, Promises and prospects of pnytoremediation. Plant Pysiology 110, 1996, 715-719.

[25] A.J.M. Baker, S.P. McGrath, C.M.D. Sidoli, and R.D. Reeves, The possibility os in situ heavy metal decontamination of polluted soil using crops of metal-accumulating plants, Resources, Conservation and Recycling 11, 1994, 41-49

[26] I. Raskin, P.B.A.N. Kumar, V. Dushenkov, and D.E. Salt, Bioconcentration of heavy metals by plants, Current Opinion in Biotechnology 5, 1994, 285-290.

[27] A.J.M. Baker, and P.L. Walker, 1990, Ecophysiology of metal uptake by tolerance plants, in A.J. Shaw (Ed) Heavy metal tolerance in plants: evolutionary aspects ( CRC Press, Boca, Raton, 1990), 155-177

[28] A.J.M. Baker, R.R. Brooks, and R.D. Reeves, Growing for gold and copper and zinc, New Science 1603, 1998, 44-48 